\title{
アモーダル補完が視覚探索に及ぼす影響は 偏心度に依存する
}

\section{白間 綾1 石口 彰 お茶の水女子大学}

\section{Eccentricity-dependent influence of amodal completion on visual search}

\author{
Aya Shirama and Akira Ishiguchi (Ochanomizu University)
}

\begin{abstract}
Does amodal completion occur homogeneously across the visual field? Rensink and Enns (1998) found that visual search for efficiently-detected fragments became inefficient when observers perceived the fragments as a partially-occluded version of a distractor due to a rapid completion process. We examined the effect of target eccentricity in Rensink and Enns's tasks and a few additional tasks by magnifying the stimuli in the peripheral visual field to compensate for the loss of spatial resolution (M-scaling; Rovamo \& Virsu, 1979). We found that amodal completion disrupted the efficient search for the salient fragments (i.e., target) even when the target was presented at high eccentricity (within $17 \mathrm{deg}$ ). In addition, the configuration effect of the fragments, which produced amodal completion, increased with eccentricity while the same target was detected efficiently at the lowest eccentricity. This eccentricity effect is different from a previously-reported eccentricity effect where Mscaling was effective (Carrasco \& Frieder, 1997). These findings indicate that the visual system has a basis for rapid completion across the visual field, but the stimulus representations constructed through amodal completion have eccentricity-dependent properties.
\end{abstract}

Key words: eccentricity effect, amodal completion, visual search.

The Japanese Journal of Psychology

2009, Vol. 80, No. 2, pp. 114-122

感覚入力がないにも関わらず，オブジェクトの遮蔽 部分が補完されて知覚される現象はアモーダル補完と よばれる (Michotte, Thinès, \& Crabbé, 1991)。プライ ミング課題や視覚探索課題を用いた研究では, アモー ダル補完の過程でどのような内部表象が形成されるの か, あるいはその処理速度等が検討されている。これ によると, 遮蔽関係にある複数の図形が入力として与 えられると, まずエッジの検出や統合等を経て 2 次元 的な表象が形成され，次にアモーダル補完によって 3 次元表象が形成される (Rauchenberger \& Yantis, 2001; Sekuler \& Palmer, 1992)。加えて, 視覚探索過程は, 補完後に消失する 2 次元的な表象に直接アクセスでき ないと考えられている(He \& Nakayama, 1992)。 Rensink \& Enns（1998）は，アモーダル補完が視覚処 理の初期において, 高速にかつ視野横断的に生じるか を, 視覚探索課題によって検討した。この研究では, Figure 1 に描かれた課題 $1 \mathrm{~A}$ と 1B の刺激が使用され Correspondence concerning this article should be sent to: Aya Shirama, Graduate School of Humanities and Sciences, Department of Psychology, Ochanomizu University, Otsuka, Bunkyo-ku, Tokyo 1128610, Japan（e-mail: shirama@jcom.home.ne.jp)

1 日本学術振興会特別研究員 DC
た。この 2 課題のターゲットはいずれも欠損した黒四 角を含む。しかし課題 $1 \mathrm{~A}$ ではターゲットが効率よく 探索されるのに対し, 課題 $1 \mathrm{~B}$ では探索効率が低下し た。Rensink \& Enns（1998）はこの結果から, 視覚処 理の初期に視野横断的なアモーダル補完が生じ, ター ゲットとディストラクターの類似性が増した後に, 視 覚探索が行われたと推量した。

一方で Kellman \& Shipley（1991）は，アモーダル補 完が複雑な形態の知識や認知的推論によって生じるの ではなく, 遮蔽によって隔てられた輪郭線の幾何学的 な空間関係に基づいて成立するモデルを提唱した。こ の幾何学的モデルや, 上述の視覚探索やプライミング を用いた研究は, 異なる方法論によって研究が進めら れてきたが，アモーダル補完がある程度ボトム・アッ プ型に成立するという点で共通している。またこのよ うな機能が視覚系の比較的初期段階に組み込まれてい るのは, 遮蔽による感覚情報の欠損が, 表面構造の復 元やオブジェクト認知の障害になるからだと考えられ ている（Rensink \& Enns, 1998）。しかし, 視野横断的 に高速なアモーダル補完が生じるという点には疑問が 残る。 
網膜の錐体密度は偏心度と共に急激に低下する。そ のためコントラスト感度関数や超視力には, 顕著な偏 心度依存性が現れる（Levi, Klein, \& Aitsebaomo, 1985; Rovamo \& Virsu, 1979)。このように視感度が低下する 視野周辺部でも, 中心視と同様にアモーダル補完を成 立させる基盤があるのだろうか。Rensink \& Enns (1998) は $12^{\circ} \times 8^{\circ}$ (固視点からの視角が最大約 $7^{\circ}$ ) の範囲に刺激を提示し, 視野横断的なアモーダル補完 過程を示唆したが，これは理論的な考察であり，実際 に高偏心度に刺激を提示する実験は行っていない。そ こで本研究では, Rensink \& Enns (1998) と同様の課 題とその類似課題を用い, 最大で偏心度 $17^{\circ}$ までの夕 ーゲット偏心度の効果を検討した。

ターゲットが提示される位置の偏心度が増加する と, 視覚探索成績が低下することが知られている (Carrasco, Evert, Chang, \& Katz, 1995)。視覚探索の偏 心度効果研究では, 皮質拡大係数を利用して刺激サイ ズを調整する手法（M 調整）がとられる（Carrasco＆ Frieder, 1997)。皮質拡大係数は, 視角 $1^{\circ}$ に対応する第 1 次視覚野の領域 (単位 $\mathrm{mm}$ ) が, 偏心度に応じて変 化する様子を表す。Rovamo \& Virsu（1979）は皮質拡 大係数を定式化すると共に，M 調整によってコント ラスト感度関数の偏心度依存性が補正できることを発 見した。そして特徴探索や結合探索にみられる偏心度 効果も $\mathrm{M}$ 調整で緩和することから, 空間解像度等の 視力要因が偏心度効果の主要因とされている (Carrasco \& Frieder, 1997)。しかしアモーダル補完を 伴うなど，図形がより複雑になる場合にも $\mathrm{M}$ 調整が 十分に機能するか, あるいは偏心度効果が残存するか はまだ知られていない。これらをふまえ本研究では, M 調整を用いて, アモーダル補完が視覚探索に与え る影響の偏心度依存性を調べた。

\section{実 験 1}

実験 1 の目的は，アモーダル補完によって効率的な 視覚探索が阻害される現象 (Rensink \& Enns, 1998) が，視野横断的に生じるかを明らかにすることであ る。そのため先行研究と同様に, Figure 1 に示される 刺激を用いた課題 $1 \mathrm{~A}$ と $1 \mathrm{~B} の 2$ 課題を行った。この 2 課題では, ターゲットの探索効率が大きく異なるこ とが, 上述の研究で示されている。課題 $1 \mathrm{~A}$ と $1 \mathrm{~B}$ の ターゲットは, どちらも, 欠損部分のある黒色四角 (欠損四角) と白円から構成されている。またディス トラクターはまったく同じ図形である。要素図形を離 してターゲットを形成する課題 1A では, セットサイ ズが探索時間に及ぼす影響は僅かで, 効率的探索が生 じる。一方で, 要素図形間に遮蔽輪郭が形成される夕 ーゲットを用いた課題 1Bでは, この影響で非効率的 な探索が生じるとされる。実験 1 では, この 2 課題に 及ぼすターゲット偏心度の効果を, 刺激サイズの効果
（刺激サイズ条件：非調整 vs. M 調整）と共に検討し た。

刺激サイズの調整係数は, 複数ある視覚野ごとに異 なり（例えばMT 野; Murakami \& Shimojo, 1995), M 調整では不適切な可能性もある。しかし, どの視覚野 の調整係数が適当かは現段階ではわからない。また Rovamo \& Virsu（1979）の計算式はV1ではなく, 空 間解像度等の網膜レベルの偏心度依存性を表現してい るという指摘もある (Levi et al., 1985)。しかし特徴探 索に限らず, 結合探索等のターゲット弁別性が低い課 題でも, Rovamo \& Virsu（1979）の M 調整は偏心度 効果の補正に効果的である（Carrasco \& Frieder, 1997 ; 白間・石口, 印刷中)。そしてこのとき, 刺激数が増 加するとターゲット偏心度に関わりなく探索成績が低 下する。

これら先行研究によって示された $M$ 調整の効果と 比較するため, 本研究では Rovamo \& Virsu (1979) の数式を用いた。もし視野上で刺激の内部表象が一様 に形成されるならば, ターゲット弁別性の高低に関わ らず $\mathrm{M}$ 調整時に偏心度効果は生じないであろう。し かし内部表象の性質が偏心度依存的に変化すれば, 従 来型とは異なる偏心度効果が生じる可能性がある。

\section{方 法}

観察者 通常視力（あるいは矯正視力）と正常な視 野を有する大学院生 5 名が実験に参加した。

装置 刺激は Power Macintosh G4 によって作成され （使用ソフト：MatLab, Psychophysics Toolbox (Brainard, 1997), グラフィックスカード：ATI Radeon7000), 21 インチの高解像度 CRT モニター（SONY CPD-G500） に提示された。画面解像度は $1280 \times 960$ pixel で, リ フレッシュレートは $60 \mathrm{~Hz}$ に設定した。

刺激 実験 1 では課題 $1 \mathrm{~A}$ と課題 $1 \mathrm{~B}$ の 2 課題を設 定し，それに対応する刺激を作成した（Figure 1)。 この 2 課題のディストラクター刺激はまったく同じだ が，ターゲット刺激として，課題 1A では欠損四角と 白円が離れた図形を, 課題 1B では欠損四角と白円が

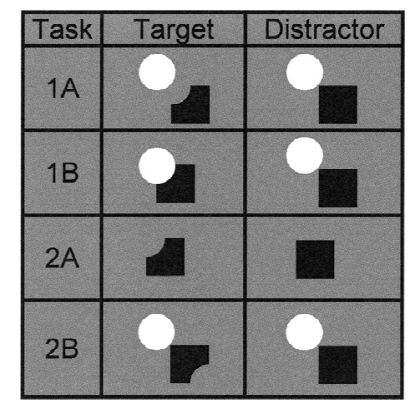

Figure 1. Illustration of the possible target and distractor stimuli in Experiments 1 and 2. 
接し, 遮蔽輪郭を形成する図形を用いた。画面の背景 輝度は $52.9 \mathrm{~cd} / \mathrm{m}^{2}$ であり，図形の輝度は白円が 95.6 $\mathrm{cd} / \mathrm{m}^{2}$, 黒色四角が $10.2 \mathrm{~cd} / \mathrm{m}^{2}$ だった。なお観察者が 図形の一部に注目し判断するのを防ぐため, ターゲッ ト, ディストラクターの中からランダムに選択して $180^{\circ}$ 回転して提示した。 $180^{\circ}$ に回転した要素数はほぼ $50 \%$ あったた。

各刺激サイズ条件の詳細は以下のとおりである。非 調整条件では偏心度に関わらず $1.1^{\circ} \times 1.1^{\circ}$ (課題 $1 \mathrm{~B}$ のターゲットのみ $\left.0.8^{\circ} \times 0.8^{\circ}\right)$ の刺激サイズを用いた。 M 調整条件では Rovamo \& Virsu (1979) らの補正係 数の算出式（式 1) に従い, 刺激サイズを $1.1^{\circ} \times 1.1^{\circ}$ から $3.8^{\circ} \times 3.8^{\circ}$ (課題 $1 \mathrm{~B}$ のターゲットのみ $0.8^{\circ} \times 0.8^{\circ}$ から $\left.2.9^{\circ} \times 2.9^{\circ}\right)$ に調整した。なお式(1)に含まれる $E$ は網膜偏心度を, $M_{0}$ は中心窩の基準拡大值 $(7.99 \mathrm{~mm} /$ deg) を示す。

$$
\begin{aligned}
M=\{ & \left(1+0.42 E+0.00012 E^{3}\right)^{-1}+(1+0.42 E \\
& \left.\left.+0.000055 E^{3}\right)^{-1}\right\} M_{0} / 2
\end{aligned}
$$

実験 1 の刺激セットサイズは $2 ， 8 ， 14$ 個とした。 刺激は $6 \times 6$ の仮想格子の交点のいずれかに，上下左 右方向に土 5 pixel（視角 $0.2 \mathrm{deg}$ ）のジターをかけて配 置され，格子の中央部を固視点とした（Figure 2)。 刺激が配置される位置は固視点からの偏心度で表した 場合, $3.4^{\circ}, 7.6^{\circ}, 10.2^{\circ}, 12.2^{\circ}, 14.0^{\circ}, 17.0^{\circ}$ の 6 水準 だった。例えば Figure 2 の灰色のセルは, 偏心度 $7.6^{\circ}$ を示している。ターゲットは各偏心度に等確率で出現 し，ディストラクターはそれ以外の場所にランダムに 配置した。つまりディストラクターは常に様々な偏心 度に出現した。これは刺激全体の提示を条件間で統一 するためである。加えて視覚探索における既存の M 調整の効果と比較するため, 先行研究 (Carrasco \& Frieder, 1997）と同様の格子状の刺激配置を使用した。 しかしこの提示法では, 固視点を基準に考えると刺激 提示位置の方位が一定ではない。例えば同じ $7.6^{\circ}$ の偏

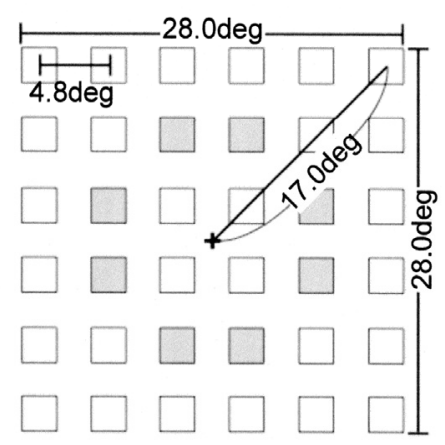

Figure 2. Stimulus configuration for the present study. Stimuli were centered at 3.4, 7.6, 10.2, 12.2, 14.0, and 17.0 deg of visual angle away from the central fixation point.For example, the shaded cells indicate $7.6 \mathrm{deg}$ of eccentricity.
心度位置（Figure 2 の灰色のセル）でも，固視点より 上方の刺激と下方の刺激が混在している。周辺視野の 異方性が視覚探索等に与える影響を調べた研究では, 下視野は上視野より，また水平方位は垂直方位より， 線分の検出力や方位弁別力が高いことが示されている (Carrasco, Talger, \& Cameron, 2002; Rezec \& Dobkins, 2004)。だが本研究では視野の異方性は問題としない ため, 視野方位ごとの結果は各ターゲット偏心度の成 績として合算した。そのため視野の異方性が指摘され ている, 4 方位（上, 下, 水平, 垂直) のいずれかに 刺激提示位置が偏った偏心度条件はなかった。

手続き 観察者は課題開始前に, ターゲットとディ ストラクターの眓形と反応方法を示した画面をみなが ら教示を受けた。観察者の課題は短時間提示される刺 激の中に，50\%の確率で現れるターゲットの有無を，

イエス・ノーの反応キーで回答することだった。観察 者にはできるだけ速く正確に回答することが求めら れ，反応時間と反応カテゴリーが記録された。

テンキーの任意のボタンを押すと, $1 \mathrm{~s}$ の固視点の 提示後, 刺激画面が $180 \mathrm{~ms}$ 現れた。毎試行の回答後 には，画面中央にフィードバックサインとして＋(正 答）かー(誤答）の記号をビープ音と共に提示した $(800 \mathrm{~ms})$ 。なお, 刺激の提示時間はサッカードの影響 を抑制するため, 平均的なサッカード潜時（約 200 ms）を下回るよう設定し, 観察者には常に画面中央 の固視点をみるよう教示した。残像にはサッカードは できないため, マスク刺激は用いなかった。1 ブロッ クは 144 試行（偏心度 6 水準 $\times$ セットサイズ 3 水準 $\times$ ターゲット有無 $\times$ 繰り返し 4 回）だった。1 ブロック 内では刺激サイズ条件は一定であった。観察者一人あ たりの総試行数は 1152 回（2ブロック×刺激サイズ 2 条件 $\times 2$ 課題 $(1 \mathrm{~A}, 1 \mathrm{~B}))$ だった。

\section{結 果}

各課題, 刺激サイズ条件においてターゲット偏心度 とセットサイズがミス率に及ぼす影響を Figure 3 に 示す。また各条件の反応時間勾配を Figure 4 に, フ オールスアラーム (FA)率を Figure 5 に示す。

通常の視覚探索課題は, 刺激提示時間を制限せず, 観察者がターゲットを発見した時点で探索が終了す る。従って誤反応（ミスとFA）率は，セットサイズ の大きい条件でも $10 \%$ 以下になることが多く, 反応 時間が探索効率の指標として用いられる。しかし本研 究のように刺激提示時間が短縮された実験では，セッ トサイズ効果は, 反応時間よりミス率に顕著に現れる 傾向がある（Carrasco et al., 1995; Rauchenberger \& Yantis, 2001)。短時間提示法は, 眼球運動や潜在的な 注意の移動による, 逐次的な探索過程を妨害すると考 えられている (Carrasco et al., 1995)。そのため探索が ターゲット発見前に打ち切られる可能性が生じる。そ 
して探索の打ち切りは, ターゲットがあったにも関わ らず，ないと答える誤反応（ミス）を引き起こす（但 しターゲットがない場合には，同様に回答しても誤反 応にはならない)。加えてセットサイズが小さければ, 探索が打ち切られる前にターゲットを発見する確率が 高いが，セットサイズが大きいほどターゲットの発見 前に打ち切りが起こる確率が高い。つまり探索効率が
低く，かつセットサイズが大きいほど，ミス率は増加 すると推測できる。実際の結果をみても，ミス率は偏 心度やセットサイズ，刺激サイズ条件などに応じて大 きく変動したが (Figure 3), RT 勾配にはこのような 変動がみられない (Figure 4)。さらにFA 率にもセッ トサイズ効果はほとんどみられない（Figure 5)。以 上から本研究では, 探索効率の指標としてミス率を使
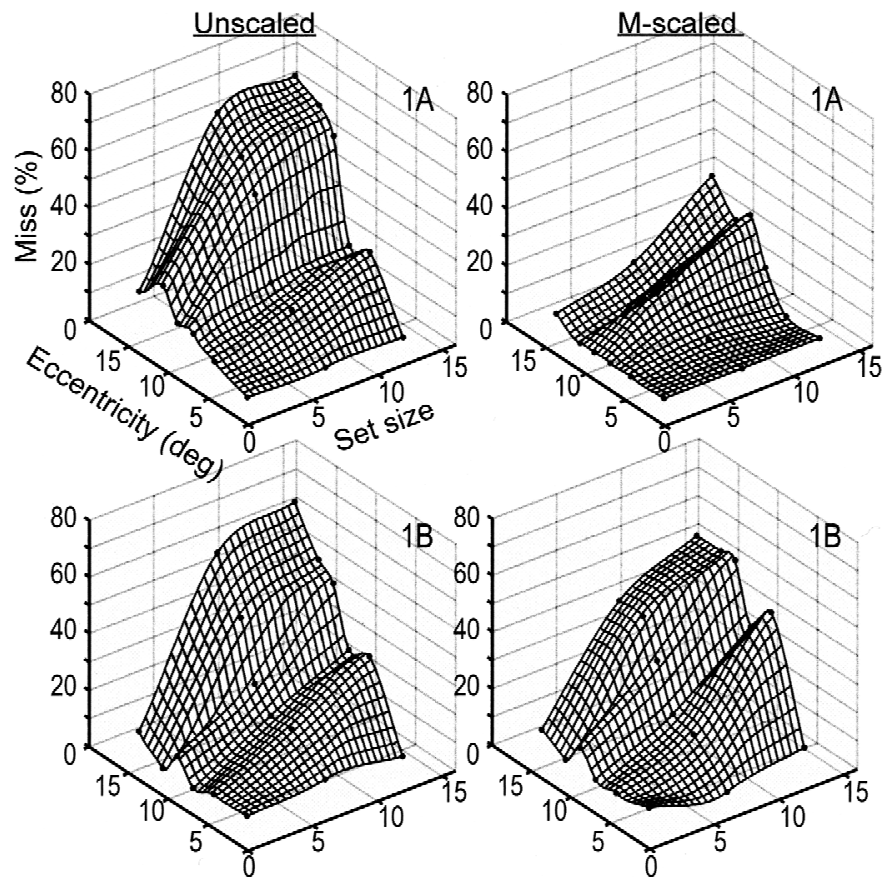

Figure 3. Observers' mean percentage of misses as a function of both set size and eccentricity in tasks $1 \mathrm{~A}$ and $1 \mathrm{~B}$.

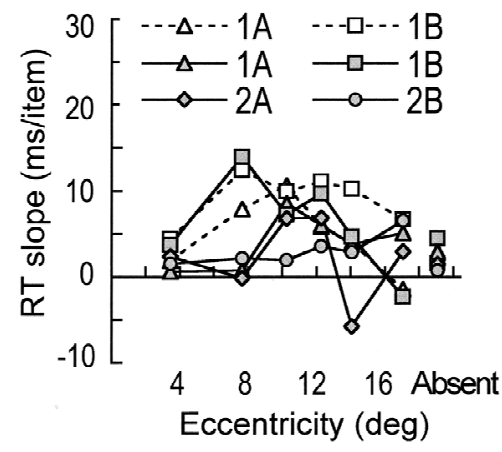

Figure 4. Observers' mean RT slopes (ms/item) as a function of eccentricity for each condition of Experiments 1 and 2. The dotted lines indicate the unscaled conditions, the solid lines the M-scaled conditions.

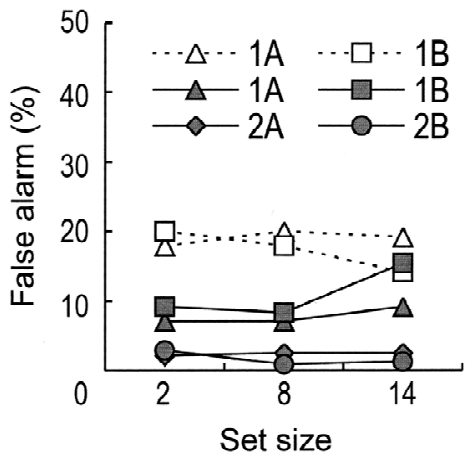

Figure 5. Observers' mean percentage of false alarms as a function of set size for each condition of Experiments 1 and 2 . The dotted lines indicate the unscaled conditions, the solid lines the M-scaled conditions. 
用した。

課題 1Aの結果 まず先行研究で効率的探索がみら れた課題 $1 \mathrm{~A}$ について, 偏心度と刺激サイズ調整の効 果を分析した。Figure 3 が示すように, この課題の非 調整時では, 偏心度の増加に伴いセットサイズ効果が 増加した。一方, $\mathrm{M}$ 調整時では非調整時ほど強い偏 心度効果は生じていない。これを統計的に確かめるた め, 観察者内の 3 要因分散分析により刺激サイズ (S), ターゲット偏心度 $(\mathrm{E})$, そしてセットサイズ (SS) がミス率に及ぼす影響を調べた。その結果, 各 要因の主効果と交互作用, ならびに 2 次の交互作用が 有意だった $(\mathrm{S}: F(1,5)=51.4, p<.001 ; \mathrm{E}: F(5$, $25)=68.6, p<.001 ; \mathrm{SS}: F(2,10)=99.1, p<.001 ; \mathrm{S} \times$ $\mathrm{E}: F(5,25)=10.7, p<.001 ; \mathrm{S} \times \mathrm{SS}: F(2,10)=8.9$, $p<.01 ; \mathrm{E} \times \mathrm{SS}: F(10,50)=27.4, p<.001, \mathrm{~S} \times \mathrm{E} \times \mathrm{SS}$ : $F(10,50)=3.1, p<.01)$ 。続いて分散分析と下位検定 として行った傾向分析により, 偏心度とセットサイズ の効果を刺激サイズ条件別に調べた。すると両刺激サ イズ条件とも, 偏心度の増加に従ってミス率が線形増 加する傾向がみられた（非調整から順に， $F(5,25)=$ $37.5, p<.001$ (線形: $F(1,5)=141.5, p<.001) ; F=$ 11.6, $p<.001(F=8.3, p<.001))$ 。加えて偏心度の増 加に伴い線形のセットサイズ効果が生じた（非調整 $\left(3.4^{\circ}\right.$ から順に)：ミス率 $0 \% ; F(2,10)=3.1, p=.06$; $F=0.9, p=.41 ; F=11.0, p<.001$ (線形: $F(1,5)=$ 17.6, $p<.001) ; F=9.7, p<.001 \quad(F=15.9, p<.001)$; $F=22.7, p<.001 \quad(F=34.0, p<.001), \mathrm{M}$ 調整：ミス 率 $0 \% ; F=1.0, p=.32 ; F=4.3, p<.05$ (線形 : $F=5.6$, $p<.05) ; F=9.8, p<.001 \quad(F=14.8, p<.001) ; F=6.7$, $p<.005(F=11.3, p<.005) ; F=5.8, p<.01 \quad(F=11.8$, $p<.001))$ 。つまり課題 $1 \mathrm{~A}$ では, 高偏心度にターゲッ トが提示されるほど，探索効率が低下したことが示さ れた。

次に刺激サイズ条件間のミス率の差分分析 (非調整 $-M$ 調整）から， $M$ 調整の効果を検討した。偏心度 水準を高低群に分け分散分析を行った結果, 偏心度と セットサイズの主効果とこれらの交互作用が有意だっ た (順に, $F(1,5)=43.9, p<.001 ; F(2,10)=9.9, p<$ $.001 ; F(2,10)=7.1, p<.005)$ 。またミス率は偏心度に 応じて線形に増加する傾向がみられ $(F(1,5)=43.9$, $p<.001)$, さらに高偏心度では線形のセットサイズ効 果が有意だった（低偏心度から順に, $F(1,5)=10.7$, $p=.53 ; F=10.7, p<.001$ (線形 $: F(1,5)=8.3, p<$ $.01))$ 。従って課題 $1 \mathrm{~A}$ の非調整時に生じた偏心度効果 は，M 調整により高偏心度のセットサイズ効果が低 下する形で緩和したことが示された。

課題 1B の結果 続いて, 先行研究で非効率的探索 がみられた課題 1B の結果を分析した。Figure 3 が示

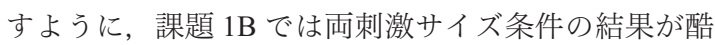
似しており，ぞちらも高偏心度ほどセットサイズ効果
が増加した。加えて課題 $1 \mathrm{~A}$ と同様に統計的分析を行 ったが，刺激サイズ要因 $(\mathrm{S})$ に関連した効果はみられ なかった $(\mathrm{S}: F(1,5)=0.1, p=.70 ; \mathrm{S} \times \mathrm{E}: F(5$, $25)=1.3, p=.28 ; \mathrm{S} \times \mathrm{SS}: F(2,10)=1.0, p=.37$; $\mathrm{M} \times \mathrm{E} \times \mathrm{SS}: F(10,50)=0.2, p=.99)$ 。すなわち課題 $1 \mathrm{~B}$ では, $\mathrm{M}$ 調整後も非調整時と同程度の偏心度効果 が残存したことが明らかになった。ちなみに偏心度と セットサイズ要因の主効果と交互作用が有意だった (順に, $F(5,25)=31.5, p<.001 ; F(2,10)=90.4, p<$ $.001 ; F(10,50)=12.3, p<.001)$ 。そこで両刺激サイズ 条件を合算し分析したところ, 偏心度の増加に伴いミ 又率が線形増加する傾向が示された $(\mathrm{E}: F(5,25)=$ $24.6, p<.001$ (線形: $F(1,5)=113.6, p<.001)) 。 ま$ た高偏心度条件 (7.6 以上) に打いて線形のセットサ イズ効果がみられた $\left(3.4^{\circ}\right.$ から順に, $F(2,10)=0.2$, $p=.81 ; F=17.4, p<.001$ (線形: $F(1,5)=34.9, p<$ $.001) ; F=19.0, p<.001(F=30.3, p<.001) ; F=24.5$, $p<.001(F=48.5, p<.001) ; F=64.5, p<.001 \quad(F=$ 79.4, $p<.001) ; \quad F=43.3, p<.001 \quad(F=70.5, p<$ .001))。以上のことから，これまで非効率的探索が生

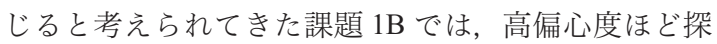
索効率が低下し, 低偏心度のターゲットは効率的に探 索されることが明らかになった。

課題 1A と 1B の比較これまでみてきた両課題の 傾向から, 探索効率はターゲット偏心度の影響を大き く受けることが示された。最低偏心度 $\left(3.4^{\circ}\right)$ にター ゲットが提示されると， M 調整の有無に関わらず, 課題 $1 \mathrm{~A}$ と $1 \mathrm{~B}$ の両課題で効率的探索が生じた。これ は先行研究と異なる結果である。さらに $\mathrm{M}$ 調整条件 における両課題の差分（1B-1A）を分析したが, 高 偏心度になるほど, 遮蔽輪郭の形成（課題 1B）で探 索効率が低下する傾向（Rensink \& Enns, 1998）が強ま ることが明らかになった。偏心度水準を高低群の 2 群 に分け分散分析を行ったところ, 偏心度とセットサイ ズ要因の主効果とこれらの交互作用が有意だった（順 に, $F(1,5)=9.1, p<.005 ; F(2,10)=14.4, p<.001$; $F(2,10)=3.8, p<.05)$ 。さらに線形の偏心度効果と,

高, 低偏心度群に打ける線形のセットサイズ効果が認 められた（順に， $F(1,5)=9.1, p<.05 ; F(1,5)=9.9$, $p<.01(F(1,5)=19.5, p<.001) ; F=10.0, p<.01$ $(F=11.5, p<.001))$ 。

一方で非調整条件も同様に分析したところ, 課題 $1 \mathrm{~A}$ は課題 $1 \mathrm{~B}$ と比較すると, 高偏心度になるほどミ 又率が単調増加する傾向がみられた $(F(1,5)=12.6$, $p<.001$ (線形: $F(1,5)=12.6, p<.001))$ 。加えてセ ットサイズの主効果は有意だが, 偏心度要因との交互 作用はみられなかったため，ミス率が全体的に大きく なる形で偏心度効果が生じたといえる(順に，F $(2$, 10) $=3.9, p<.05 ; F(2,10)=0.2, p=.83)$ 。このことか ら, 高偏心度で探索成績のよい課題は, 刺激サイズ条 
件ごとに異なることがわかった。非調整下では空間解 像度等の視力低下により, 高偏心度の探索成績が低下 すると考えられる。その状況で, この結果が得られた ということは, 図形の平均輝度や輝度変化といった, 非形態情報が影響した可能性が考えられる。このとき 白円と黒色四角が接している課題 1B の方が課題 $1 \mathrm{~A}$ よりも図形の輝度変化が大きく, ターゲットの視認性 が高かった可能性がある。

\section{考 察}

実験 1 では, 遮蔽輪郭の有無によりターゲットの弁 別性が変化する傾向（Rensink \& Enns, 1998）が, 偏心 度横断的にみられるかを検討した。まず非調整条件で は, 両課題とも顕著な偏心度効果が生じた。非調整で は比較的小さな刺激を偏心度横断的に提示したため, 高偏心度では空間解像度が低下する影響を受け, ター ゲットの弁別が阻害されたと考えられる。一方の M 調整条件では, 空間解像度の低下を補うため, 高偏心 度の刺激を拡大して提示した。この操作により, 課題 $1 \mathrm{~A}$ の $\mathrm{M}$ 調整では非調整時に比べ偏心度効果が緩和し た。ところが課題 1B では， M 調整後も顕著な偏心度 効果が残存した。Rensink \& Enns（1998）は，この課 題ではアモーダル補完によりターゲットとディストラ クターの形態が類似し，非効率的探索がみられると報 告した。だが M 調整下で低偏心度に現れたターゲッ トは，セットサイズの影響をほとんど受けず効率的に 探索されたのに対し, 高偏心度にターゲットが提示さ れると探索が非効率化した。先行研究では比較的狭い 範囲（固視点からの視角が最大 $7^{\circ}$ ) に刺激を提示し, ターゲット偏心度の成績を合算したため, 偏心度の影 響が結果に現れなかったと推測される。

さらに課題 $1 \mathrm{~B}$ の $\mathrm{M}$ 調整後の偏心度効果は, 従来 の研究にはないものである。これまで, M 調整は結 合探索等のターゲット弁別性が低い課題において, 夕 ーゲットの偏心度によらず一定のセットサイズ効果を もたらすことが報告されている (Carrasco \& Frieder, 1997 ; 白間・石口, 印刷中)。だが線分等を用いた先 行研究と本研究では, 使用した図形の複雑性が大きく 異なる。従って課題 $1 \mathrm{~B}$ での $\mathrm{M}$ 調整後の偏心度効果 は, 図形の処理特性によって生じたことが考えられ る。

しかし先行研究で効率的探索が観察された課題 $1 \mathrm{~A}$ でも， $\mathrm{M}$ 調整時に偏心度効果が残存した。このため 高偏心度において, 高速なアモーダル補完が効率的探 索を阻害する現象を確認できなかった。そこで次の実 験 2 では実験 1 の類似課題を用い, 高偏心度に打いて 要素図形の配置が, ターゲットの顕著性に及ぼす影響 を検討した。

\section{実 験 2}

実験 2 では, 実験 1 の課題 1B（M 調整時）におい て, 高偏心度のターゲットに対し非効率的探索が生じ たのは, 高速なアモーダル補完によるのかを再検討す る。先行研究では, 課題 $1 \mathrm{~A} と 1 \mathrm{~B}$ のターゲットに含 まれる欠損四角は, 形態的な顕著性をもつとしてい る。そして顕著性をもつ図形の視覚探索が, 久損四角 と白円の配置に依存して, 効率的探索加ら非効率的探 索へと変化することから, 高速なアモーダル補完過程 を示唆した。だが実験 1 ではターゲットが顕著である はずの課題 $1 \mathrm{~A}$ でも, 高偏心度では探索効率が低下し た。このため遮蔽輪郭を形成する図形配置の効果が, 欠損四角の特徵に対して作用したのかが疑問として残 った。欠損四角は高偏心度において顕著な特徵ではな

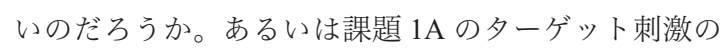
ような図形配置でも, 高偏心度では欠損四角の顕著性 が低下してしまうのだろうか。

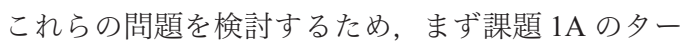
ゲットとデイストラクターから白円を除き図形を単純 化した課題 $2 \mathrm{~A}$ を行い, 高偏心度に打ける久損四角の 顕著性を調べた。さらに四角形の欠損部とは反対側に 白円を配置した図形をターゲットとした課題 2B を実 施した。この配置では遮蔽輪郭が形成されないため, 欠損四角のアモーダル補完は起きないと予想される。 最後に実験 1,2 の結果を比較し, 高偏心度において, 要素図形の配置とアモーダル補完が欠損四角の顕著性 に与える影響を吟味した。

\section{方 法}

観察者と手続きは実験 1 と同様で, 観察者一人あた りの総試行数は 576 回 $(2$ ブロック $\times 2$ 課題 $(2 \mathrm{~A}$, 2B)）だった。

刺激課題 $2 \mathrm{~A}$ と $2 \mathrm{~B}$ の 2 課題に対応する刺激を作 成した。具体的には課題 $1 \mathrm{~A}$ で使用した図形を基本と し, これから白円を取り除いたものを課題 $2 \mathrm{~A} に$ に, 四 角形の欠損部を白円の反対側に向けたものを課題 $2 \mathrm{~B}$ に用いた (Figure 1)。また課題 2B のディストラク夕 一は課題 $1 \mathrm{~A}$ と同じであり, 図形や背景の輝度は実験 1 と同じだった。なお実験 2 では $\mathrm{M}$ 調整時に生じる 偏心度効果を検討するため, 非調整条件は実施せず $\mathrm{M}$ 調整条件のみを行った。

\section{結果と考察}

課題 $2 \mathrm{~A}$ と $2 \mathrm{~B}$ において, 偏心度とセットサイズが ミス率に及ぼす影響を Figure 6 に示す。また各条件 の反応時間勾配を Figure 4 に, FA 率を Figure 5 に示 す。

Figure 6 から明らかなように, 実験 2 では顕著な偏 心度効果やセットサイズ効果がみられない。これを統 
計的に確認するため, 観察者内の分散分析により，ミ ス率に対する偏心度とセットサイズの効果を検討し た。その結果, 課題 $2 \mathrm{~A}$ では偏心度要因の主効果と交 互作用はみられず, 線形傾向のないセットサイズの主 効果が有意だった（順に， $F(5,25)=1.7, p=.16$; $F(10,50)=1.5, p=.18 ; F(2,10)=4.6, p<.05$ (線形 : $F(1,5)=5.4, p=.06)$ 。一方課題 $2 \mathrm{~B}$ では, ミス率に おけるセットサイズ要因の主効果や交互作用はみられ ず，偏心度要因にも線形傾向はみられない（順に， $F(2,10)=1.0, p=.38 ; F(10,50)=1.2, p=.31 ; F(5$, $25)=7.7, p<.001($ 線形 : $F(1,5)=1.6, p=.15)) 。 \supset$ まり両課題の成績には, 単調増加傾向を示す偏心度効 果やセットサイズ効果はみられない。さらに全ターゲ ット偏心度の反応時間勾配は, $10 \mathrm{~ms} / \mathrm{item}$ 未満だった (Figure 4) ことから, 実験 2 の 2 課題では, 広い視 野領域で効率的な探索が生じたことが示唆される。こ のことから, 欠損四角の特徴は高偏心度でも顕著性を もち, 効率的に探索されることが示された。また課題 1A のターゲットのような要素図形の配置でも, 高偏 心度では欠損四角の顕著性が低下することがわかっ た。高偏心度では，オブジェクト間の空間的ずれを検 出するヴァーニア視力が低下する (Levi et al., 1985)。 そのため課題 1A のターゲットに含まれる, 要素図形 の空間的ずれの検出精度が低下し，アモーダル補完が 生じるといった影響が現れた可能性も考えられる。

一方で 2B, 1B の 2 課題は, いずれも同じ要素図形 から刺激が構成されていた。そして四角形の欠損部の 反対側に白円を配置した課題 $2 \mathrm{~B}$ は, 課題 $2 \mathrm{~A}$ と同様 に偏心度横断的に効率的探索がみられた。ところが課 題 $1 \mathrm{~B}$ において四角形の欠損部に白円が接すると, と くに高偏心度の探索効率が低下している。従って遮蔽 輪郭の形成が，効率的に探索できる欠損四角の形態的 性質に大きな影響を与えることが示された。以上の結 果から, 高偏心度に拈ける高速なアモーダル補完過程 の存在が示唆される。

\section{総合的考察}

アモーダル補完に関する研究では, ボトム・アップ 型の処理過程を基礎とした高速補完が視野横断的に成 立すると考えられてきた（Kellman \& Shipley, 1991; Rensink \& Enns, 1998)。しかしこれまで視野の空間的 不均一性の影響は，ほとんど言及されてこなかった。 そのため本研究では M 調整を利用し, まず高速なア モーダル補完によってターゲットの弁別性が変化する 現象が, 視野横断的に現れるかを検討した。その結 果, この現象が広域の視野領域 (本研究では偏心度 $17^{\circ}$ まで検討）で生じることを示唆する，先行研究と 一致した結果が得られた。

自然環境下では, 多くのオブジェクトが互いに遮蔽 関係をもち存在する。そのため遮蔽された部分から は, 感覚入力が得られない。これに対応するため, 視 覚系には広域の視野上で不可視部分の構造を復元する ための, 基盤が備わっていると考えられる。加えて視 覚的注意研究では, 視野横断的かつ高速に, プロト・ オブジェクトとよばれる内部表現が形成されると考え られてきた（Driver, Davis, Russell, Turatto, \& Freeman, 2001)。プロト・オブジェクトには, 面の明るさや輪 郭線の方位等の画像的情報だけでなく, 面の凹凸や照 明方向といった光景の 3 次元的情報が含まれる (Enns \& Rensink, 1990; Ramachandran, 1988)。本研究の結果 から示唆される, 視野横断的で高速なアモーダル補完 過程も,このような視覚系の働きの一部と捉えること ができる。しかしプロト・オブジェクトのような内部 表現が, 視野上で一様に構築されるかは, 慎重に検討 する必要がある。

その理由として第一に, 刺激が提示される偏心度 は, 内部表象が適切な空間解像度で形成されるか否か に重要な影響をもたらすことが挙げられる。実験 1 の 非調整条件でも, 空間解像度等の視力低下によって, 高偏心度では夕ーゲット弁別性が大きく低下する現象

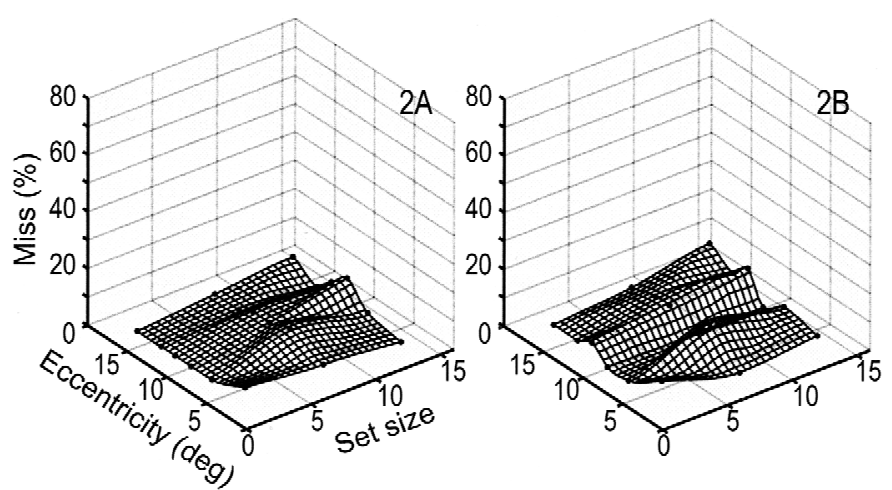

Figure 6. Observers' mean percentage of misses as a function of both set size and eccentricity in tasks $2 \mathrm{~A}$ and $2 \mathrm{~B}$. 
がみられた。そして第二に，アモーダル補完が視覚探 索に及ぼす影響が，偏心度に依存していたことが挙げ られる。Rensink \& Enns (1998) の研究で非効率的探 索が観察された課題 1B では, M 調整後に顕著な偏心 度効果が生じ, 低偏心度のターゲットは効率的に探索 された。このとき低偏心度から得られたオブジェクト 情報には, 高偏心度のものにはない, 何らかの顕著性 が含まれていた可能性がある。これは低偏心度におい て，アモーダル補完が起きないことを意味しているの だろうか。

Rauchenberger \& Yantis（2001）は, 重なり図形を利 用した視覚探索の研究を行った。この中でマスク刺激 と刺激画面の SOA (stimulus onset asynchrony) を 100 $\mathrm{ms}$ に制限する手法により, アモーダル補完前の 2 次 元的な表象の存在を明らかにした。もしアモーダル補 完以前の図形特性を利用できるならば，課題 $1 \mathrm{~B}$ の夕 ーゲットは目立ちやすい欠損四角を含むので効率的に 探索できる。だが従来のアモーダル補完研究は, 主に 固視点部に刺激を提示して実験を行っているものが多 く, $200 \mathrm{~ms}$ 程度の提示時間 (本研究の刺激提示時間 はマスクなしで $180 \mathrm{~ms}$ だった）で補完の影響が現れ ることが示されている (Sekuler \& Palmer, 1992)。こ れをふまえると, 課題 $1 \mathrm{~B} て ゙$ て低偏心度に現れたターゲ ットにアモーダル補完の影響がなかったとは考えがた い。加えて視覚探索場面において，アモーダル補完後 にも補完以前の情報が利用できることを示した研究は ない。従ってアモーダル補完は偏心度横断的に生じう るが, 重なりをもつ図形の内部表現が偏心度に依存し て変化する可能性が考えられる。

こういった形態処理における偏心度依存性の一つと して, 空間不確定性の問題がある。垂直に並べられた 三つのガボールパッチの内, 中央のパッチのずれを検 出する課題では, コントラスト弁別では偏心度依存性 がみられなかった空間周波数パッチを用いても, 高偏 心度の検出力は低下する (Hess \& Field, 1993)。課題 1Bで使われた図形を振り返ってみると, 補完が生じ た場合には, 図形が重複したものがターゲットで, 離 れたものがディストラクターと捉えることもできる。 アモーダル補完を受けた被遮蔽面と遮蔽面の奥行き関 係（3 次元的な空間関係）によってターゲットとディ ストラクターが設定される課題では, 探索は非効率的 になることが知られる (Moore, Elsinger, \& Lleras, 2001)。だが空間不確定性の影響で, 空間関係の弁別 力は特に高偏心度で低下する可能性がある。

この仮説の検討は今後の課題として残されるが, 今 回の研究から, 刺激が提示される偏心度が, 形態処理 と視覚探索過程に複雑な影響を及ぼすことが明らかに なった。線分等の比較的単純な困形を用いた視覚探索 課題では，ターゲット弁別性が低い場合に，M 調整 は偏心度横断的に一定のセットサイズ効果を生じさせ
る (Carrasco \& Frieder, 1997 ; 白間 - 石口, 印刷中)。 しかし,アモーダル補完が生じる図形を探索する場合 には, 形態処理の複雑性によって, $\mathrm{M}$ 調整後にも偏 心度効果が現れる。これをもたらす要因として, 複数 の視覚野ごとに皮質拡大係数の值が異なる, という問 題がある。例えば上記の空間の不確定性にも関連す る, 図形の空間的ずれを検出するヴァーニア視力の偏 心度依存性は, Rovamo \& Virsu（1979）の計算式とは 異なる拡大率の調整係数によって補正できる（Levi et al., 1985)。そのため調整係数の問題が, 課題 1B の M 調整時に偏心度効果を引き起こしたとすれば, 適切な 調整係数の利用でこれを補正できる可能性がある。引 き続き, 視野の空間的不均一性が, 視空間の 3 次元構 造の復元過程と, 視覚的情報選択に及ぼす影響を明ら かにしていく必要がある。

\section{引用文献}

Brainard, D. H. (1997). The Psychophysics Toolbox. Spatial Vision, 10, 433-436.

Carrasco, M., Evert, D. L., Chang, I., \& Katz, S. M. (1995). The eccentricity effect: Target eccentricity affects performance on conjunction searches. Perception and Psychophysics, 57, 1241-1261.

Carrasco, M., \& Frieder, K. S. (1997). Cortical magnification neutralizes the eccentricity effect in visual search. Vision Research, 37, 63-82.

Carrasco, M., Talger, C. P., \& Cameron, E. L. (2002). Characterizing visual performance fields: Effects of transient covert attention, spatial frequency, eccentricity, task and set size. Spatial Vision, 15, 61-75.

Driver, J., Davis, G., Russell, C., Turatto, M., \& Freeman, E. (2001). Segmentation, attention and phenomenal visual objects. Cognition, 80, 61-95.

Enns, J. T., \& Rensink, R. A. (1990). Influence of scenebased properties on visual search. Science, 247, 721723.

He, Z. J., \& Nakayama, K. (1992). Surfaces versus features in visual search. Nature, 359, 231-233.

Hess, R. F., \& Field, D. (1993). Is the increased spatial uncertainty in the normal periphery due to spatial undrsampling or uncalibrated disarray? Vision Research, 33, 2663-2670.

Kellman, P. J., \& Shipley, T. F. (1991). A theory of visual interpolation in object perception. Cognitive Psychology, 23, 141-221.

Levi, D. M., Klein, S. A., \& Aitsebaomo, A. P. (1985). Vernier acuity, crowding and cortical magnification. Vision Research, 25, 963-977.

Michotte, A., Thinès, G.S., \& Crabbé, G. (1991). Amodal completion and perceptual structures. In G. S. Thinès, A. Costall, \& G. Butterworth (Eds.), Michotte's experimental phenomenology of perception. Hillsdale, NJ: Laurence Erlbaum Associates. pp. 140-167.

Moore, C. M., Elsinger, C. L., \& Lleras, A. (2001). Visual 
attention and the apprehension of spatial relations: The case of depth. Perception and Psychophysics, 63, 595-606.

Murakami, I., \& Shimojo, S. (1995). Modulation of motion aftereffect by surround motion and its dependence on stimulus size and eccentricity. Vision Research, 35, 1835-1844.

Ramachandran, V. S. (1988). Perceiving shape from shading. Scientific American, 259, 76-83.

Rauchenberger, R., \& Yantis, S. (2001). Masking unveils pre-amodal completion representation in visual search. Nature, 410, 369-372.

Rensink, R. A., \& Enns, J. T. (1998). Early completion of occluded objects. Vision Research, 38, 2489-2505.

Rezec, A. A., \& Dobkins, K. R. (2004). Attentional weighting: A possible account of visual field asymmetries in visual search? Spatial Vision, 17, 269-293.

Rovamo, J., \& Virsu, V. (1979). An estimation and application of the human cortical magnification factor. Experimental Brain Research, 37, 495-510.

Sekuler, A. B., \& Palmer, S. E. (1992). Perception of partly occluded objects: A microgenetic analysis. Journal of Experimental Psychology: General, 121, 95-111.

白間綾・石口彰 (印刷中)。視野の空間解像度 勾配と視覚サンプリングの柔軟性 心理学研究 (Shirama, A., \& Ishiguchi, A. (in press). Spatial resolution gradient of the visual field and flexibility of visual sampling. Japanese Journal of Psychology.)

-2008. 2. 27 受稿, 2009.1.24 受理—— 